\title{
Making authentic: exploring boundary objects and bricolage in knowledge mobilisation through National Health Service-university partnerships.
}

Melville-Richards ${ }^{1}$, LA, Rycroft-Malone ${ }^{2}$, J, Burton ${ }^{3}$, C, Wilkinson 4 , J, 2019, Evidence \& Policy - in press

${ }^{1}$ Bangor University

${ }^{2}$ Bangor University

${ }^{3}$ Bangor University

${ }^{4}$ University of Stirling

\section{Abstract:}

Background: In healthcare, bridging the research-to-practice gap is a top priority. Knowledge mobilisation scholars suggest that this gap can be closed through collaboration between knowledge users and producers. The concept of boundary objects - shared things and ideas that enable communication, has gained popularity across various collaborative work practices, but their potential within knowledge mobilisation in healthcare is understudied. An ongoing challenge for designers of boundary objects is how to create objects that are valued and shared both in principle and in practice.

Aims and objectives: This paper reports on a study of boundary objects used during knowledge mobilisation through NHS-university partnerships called Collaborations for Leadership in Applied Health Research and Care (CLAHRCs). The distinction is investigated between boundary objects-in-theory and boundary objects-in-use, considering whether the latter possess specific characteristics which make them more effective during knowledge mobilisation.

Methods: A qualitative case study of three CLAHRCs was conducted. 21 people employed as 'boundary spanners' were interviewed to explore whether boundary objects played a role in knowledge mobilisation.

Findings: The most effective boundary objects-in-use were co-produced through a process of bricolage. These possessed high levels of meaningfulness, resonance, and reconciled multiple user perspectives. Together these properties contributed to the overall authenticity of boundary objectsin-use.

Discussion and conclusion: This paper helps to explain why designated boundary objects frequently fail in practice, and why there is a need to focus on understanding boundary objects based on symbolic, rather than structural, dimensions.

\section{Key words:}

Boundary object, bricolage, co-production, knowledge mobilisation

Word count: 7814 


\section{Introduction}

The global move towards more evidence-based healthcare has been hindered by what has been labelled as the 'research-practice gap'; a gap between 'what is known' from research and 'what is done' in practice, with serious implications for patient care (Nutley and Davies, 2001; Greenhalgh et al, 2004; Estabrooks et al. 2006; Graham et al., 2006,). One proposed solution is for research producers and consumers to work more closely together during the knowledge creation and use process (Nonaka, 1994; Nowotny et al. 2001; Grimshaw et al, 2012).

This paper reports on a study exploring the role of boundary objects during knowledge mobilisation in the context of university-NHS partnerships named Collaborations for Leadership in Applied Health Research and Care (CLAHRCs). It takes its starting point from Levina and Vaast's (2005) proposition that there exist 'designated boundary objects' which, although intended to help facilitate the transfer of information/knowledge across boundaries, may not actually do so in practice. They distinguish between these designated, or intended objects, and boundary objects-in-use, the actual things used to cross boundaries in the real-world. In this paper we further investigate this distinction by asking what is it that facilitates the transition from designated to boundary object-inuse. The term boundary objects-in-theory replaces Levina and Vaast's (2005) designated objects as it emphasises the many objects that can operate as boundary objects without necessarily being intended to do so, as a consequence, rather than as a purpose, of their design. We consider whether boundary objects-in-use possess specific characteristics which make them more effective in practice. The role of co-production as a type of collective bricolage (Levi-Strauss, 1962) in the generation of boundary objectsin-use is explored, as are the gaps in the process which can lead to poor uptake, the 
creation of insufficiently meaningful objects, or of objects which provoke conflict rather than unifying stakeholders to work together during knowledge mobilisation.

\section{Background and context}

In England, one policy aimed at closing the gap between research and practice was to establish multi-disciplinary partnerships. Originally named CLAHRCs, the partnerships were intended to increase the generation of applied health research alongside accelerating the rate at which research was translated into practice by connecting and aligning researchers, practitioners, patients and policy-makers (NIHR, 2008). The arrival of CLAHRCs prompted the commissioning of evaluation studies of which this study was a part. This paper reports on one aspect of the study's findings: the properties of boundary objects-in-use, and the process by which these are instilled.

\section{Boundary objects}

Boundary objects are shared things or ideas which are used to open up communication across boundaries, for example between different professional groups (Carlile, 2002). They possess strong cohesive properties and have multiple meanings, but remain recognisable across different settings (Star and Griesemer, 1989).

Star proposed the concept in 1989 in the context of a study of the Berkeley Museum of Vertebrate Zoology. She found that a range of stakeholders were able to coordinate their work to collect, organise, and exhibit specimens, despite having different motivations for doing so. She suggested that the way in which these different groups were able to work together, for example populating and maintaining the museum's catalogue and hosting exhibitions, was through the use of shared 'boundary objects'. 
Star (1989) identified four categories of boundary object: repositories, ideal types, coincident boundaries and standardised forms.

A key function of boundary objects is to enable "one group to speak to another" (Carlile, 2002) by providing a shared language which is meaningful to all stakeholders.

Considerable attention has been paid to the collaborative potential of boundary objects, for example Winget (2007) and Phelps and Reddy (2009). The literature reviewed revealed that whilst certain material aspects of boundary objects have been well explored, for example Henderson's (1991) study of computer assisted design (CAD) use, Ackerman and Halverson's (2004) exploration of employee payroll records, Koskinen and Makinen's (2009) investigation of engineering project contracts, and Osterlund and Crowston's (2013) exploration of the role of documents in online communities, there is less research into the vague and symbolic dimensions to which Star (1989) originally alluded. Notable exceptions include Levina and Vaast (2005), Briers and Chua (2001), and Fox (2011).

The persuasive properties of boundary objects are examined by Briers and Chua (2001), who proposed a new category to add to those of Star's: that of 'visionary object'. Visionary objects are concepts which evoke an affective response, making it "difficult for a 'rational' person to be against them" (p. 242). Levina and Vaast (2005) direct attention to boundary spanning in practice compared to aspirational boundary spanning in theory (p.336), highlighting a disparity between what is intended and what actually occurs.

Designing objects for boundary spanning

The literature suggests that boundary spanning activities can sometimes lead to conflict and confrontation rather than collaboration, for example if inadequate shared 
meanings are attached to an object, or if the object represents the focus of competing or opposing agendas (Carlile, 2002; Levina and Vaast, 2005; Barrett and Oborn, 2010). Other issues relate to the loss of interpretive flexibility of boundary objects. For example, Henderson (1991) demonstrates how CAD is insufficiently flexible to accommodate multiple perspectives, compared with traditional technical drawings which can be readily modified to integrate additional information, or when a designated boundary object is rejected by users in preference for a boundary-objectin-use (Levina and Vaast, 2005).

Evidence suggests that the utility of a boundary object may be enhanced symbolically rather than by design, highlighting users' preference for the familiar, trusted and meaningful (Briers and Chua, 2001; Stenfors, Tanner and Haapalinna, 2004; Levina and Vaast, 2005; Phelps and Reddy, 2009; Fox, 2011). However, recreating the emotive symbolism and preserving the interpretative flexibility exhibited by well-used boundary objects has proved challenging for designers (Van Kammen, 2003; Atwell, 2011).

Applying the concept of boundary objects to the research-practice gap in healthcare Knowledge mobilisation in healthcare is recognised as a complex, iterative endeavour in which collaboration at an individual and organisational level to span multiple, diverse boundaries is key (Rycroft-Malone at al, 2004; Graham et al, 2006; Kitson et al, 2008; Baumbusch et al, 2008; Damschroder et al, 2009; Blevins et al, 2010; Cooke et al, 2015; Rycroft-Malone et al, 2015; and 2016). Harnessing boundary objects to enable 
collaboration between knowledge producers and knowledge users aligns with the agenda to increase knowledge uptake and thus improve patient outcomes.

A number boundary objects have been identified within healthcare, for example an exploration of concepts used in oncology (Fujimara, 1992), the classification of diseases (Bowker and Star, 1999), the use of shared information systems to coordinate medical care (Reddy, Dourish and Pratt, 2001), clinical care pathways (Allen, 2009; 2014), and innovation uptake in surgical sterility (Fox, 2011). Oborn et al. (2010) have called for further investigation of the role of these objects in knowledge mobilisation in healthcare.

A broader review of the literatures relating to boundary objects and knowledge work is presented by Melville-Richards (2015), whilst Kislov et al (2011) provide a comprehensive account of the associated domain of communities of practice within CLAHRCs. Williams (2012) offers a useful route into the twin field of boundary spanners within a public policy and practice context, whilst Nicolini et al (2008) provide a thorough review of knowledge management in healthcare, covering boundaries and the objects involved.

This paper updates Levina and Vaast's (2005) distinction of designated boundary objects to boundary objects-in-theory to clarify that many things can be identified on paper as boundary objects; this may be as an unanticipated consequence of their design, rather than a deliberate choice on the behalf of the designer. It continues in the footsteps of Briers and Chua (2001) by developing their category of 'visionary objects' to become symbolic objects, that is, objects that possess both persuasive and affective properties, and which despite immateriality become representative of shared assumptions and embedded social meanings (Fox, 2011). Symbolic objects can harbour an ingrained social value and provoke an emotional response which may be 
positive or negative for different users, as in Allen's (2014) proposition of positive and negative boundary objects. This paper seeks to fill a gap in the evidence about the role of boundary objects during knowledge mobilisation in healthcare, addressing the ongoing challenge of designing effective boundary objects-in-use rather than those which remain of limited utility as boundary objects-in-theory. Central to the paper is the question of what distinguishes a boundary object-in-theory from one in-use, and whether there is a process of transition which can be unpacked to reveal ways to increase the likelihood that this will occur.

\section{Methods}

A multiple case study approach was taken (Simons, 2009; Thomas, 2011), in which three CLAHRCs (anonymised as Oakdown, Hazeldean and Ashgrove) represented three single cases (Table 1), within which 21 people in boundary spanning roles ('boundary spanners') were considered as embedded units. Boundary spanners were purposively sampled because the nature of their work within CLAHRC meant that they were likely to be negotiating boundaries between academia and the NHS, and as such were likely to encounter boundary objects. Boundary spanners were represented by a variety of job titles, including 'knowledge transfer associate', CLAHRC 'coordinator' and 'facilitator' (Table 2).

A refined boundary object taxonomy which consolidated Star's (1989), Briers and Chua's (2001), Carlile's (2002) and Levina and Vaast's (2005) work was generated as an outcome of a preliminary literature review (Table 3). Carlile's (2002) description of objects, models and maps was included as it merged the sort of things that Star (1989) had originally included in her 'ideal types' and 'coincident boundaries' categories. The 
category of 'visionary objects' is updated to 'symbolic objects' in order to clarify their potentially provocative nature; as a descriptor 'visionary' has connotations of unifying positivity which may not always be appropriate. This taxonomy provided the basis of an initial coding framework which was used to interrogate documents sampled across the three cases to identify whether any boundary objects-in-theory that were evident in the three CLAHRCs' intentions and plans (e.g. documents relating to knowledge mobilisation activity within each CLAHRC such as annual reports, journal articles and other publically accessible outputs), performed as, or were aligned with, those that were identified in accounts of knowledge mobilisation (boundary object-in-use). Some examples that were identified are shown in Table 2.

Semi-structured in-depth interviews were conducted with a total of 21 boundary spanners from across the three CLAHRCs. Participants were identified through snowball sampling (Patton, 2002), initiated via key members of each CLAHRC's leadership team. Where possible interviews were conducted face-to-face, others were carried out over the telephone for practical reasons. Each was structured around a schedule of open-ended questions focused on participants' experiences of knowledge mobilisation, exploring the things and ideas that had been useful and shared (or not) during this process. Each interview lasted between 45 and 90 minutes, and was transcribed verbatim. The transcripts were analysed using a framework (Ritchie and Spencer, 1994) that had been developed previously (Table 3). The framework provided a way into the data, but was used flexibly so that new ideas and concepts could surface as interviews progressed. Data were analysed within cases, and then across cases. A deliberative team approach was used to scrutinise emerging findings, during which the Principal Investigator and core research team met to compare, contrast and reflect on emergent patterns and themes within the data (Ritchie and Lewis, 2003). 
Ethical approval was granted via the Coordinated System for NHS Permission (CSP reference 96980).

Table 1: Case Summaries

\begin{tabular}{|c|c|}
\hline Oakdown & $\begin{array}{l}\text { Oakdown CLAHRC consists of a partnership between two regional } \\
\text { universities, } 12 \text { NHS Trusts, a children's charity and an online } \\
\text { innovation hub organisation. It is made up of four metropolitan } \\
\text { boroughs with a population of } 1.34 \text { million, who are mainly white } \\
\text { with Asian or British Asian people being the larger, other ethnic } \\
\text { group. There exist pockets of severe deprivation and related poor } \\
\text { health, disability, and high unemployment. Life expectancy is } 10.7 \\
\text { years lower for men and } 7.7 \text { years lower for women in the most } \\
\text { deprived areas. Health priorities identified by Public Health England } \\
\text { were addressing health inequalities, smoking, and mental health. } \\
\text { Early deaths from cancer and stroke are higher than the England } \\
\text { average, and } 19.3 \% \text { of children in year } 6 \text { (age } 10 \text { years) were } \\
\text { classified as obese. Oakdown has created joint roles i.e. appointing } \\
\text { individuals with clinical experience into strategic, managerial and } \\
\text { frontline implementation roles. Oakdown is characterised by } \\
\text { individuals in leadership roles who possess both theoretical and } \\
\text { practical knowledge of implementation. This knowledge drives a } \\
\text { clear vision of what implementation is and how CLAHRC can meet } \\
\text { the needs of the NHS and the population it serves. Boundary } \\
\text { spanners at Oakdown are typically seconded clinical staff employed } \\
\text { within the local NHS, with mixed levels of experience of research or } \\
\text { service improvement. }\end{array}$ \\
\hline Hazel & $\begin{array}{l}\text { Hazeldean CLAHRC was made up of a partnership between a large } \\
\text { city university and four regional Clinical Commissioning Groups } \\
\text { (CCGs) serving a mixed population of } 2.5 \text { million which is } \\
\text { comparable in terms of diversity to the population of England as a } \\
\text { whole. Deprivation indices (2010) showed a mixed picture of poverty } \\
\text { across the area, with pockets of severe deprivation around the main } \\
\text { city and in some outlying boroughs. Vascular conditions were seen } \\
\text { by the CLAHRC as a priority and included diabetes, coronary heart } \\
\text { disease, chronic kidney disease and stroke. } \\
\text { These CCGs have replaced the original ten Primary Care Trusts } \\
\text { (PCTs) and NHS Trusts which represented the NHS partners during } \\
\text { the first four years of CLAHRC. There is evidence that this } \\
\text { organisational change in the NHS has impacted across CLAHRC, } \\
\text { with role uncertainty damaging relationships within the partnership. } \\
\text { Organisational division is also evident across the partnership itself } \\
\text { as demonstrated by the segregation of Hazeldean's } \\
\text { 'implementation' theme from its 'research' theme, automatically } \\
\text { assuming boundaries between the two work streams. Boundary }\end{array}$ \\
\hline
\end{tabular}




\begin{tabular}{|l|l|}
\hline spanners at Hazeldean were typically graduates or people with \\
experience in industry, academia and project management. \\
However as Hazeldean CLAHRC matured, more NHS employed \\
secondees were recruited into boundary spanning roles, as it was \\
found that their skills and experience of the NHS provided important \\
'insider' knowledge.
\end{tabular}

Table 2: participants interviewed

\begin{tabular}{|c|c|c|}
\hline Ashgrove & Hazeldean & Oakdown \\
\hline 6 telephone interviews & 8 telephone interviews & $\begin{array}{l}7 \text { interviews, } 5 \text { face-to- } \\
\text { face plus } 1 \text { via telephone }\end{array}$ \\
\hline 3 CLAHRC coordinators & $\begin{array}{l}5 \text { knowledge transfer } \\
\text { associates }\end{array}$ & $\begin{array}{l}2 \text { knowledge translation } \\
\text { facilitators }\end{array}$ \\
\hline 1 academic lead & 2 academic leads & $\begin{array}{l}1 \text { CLAHRC knowledge } \\
\text { translation lead }\end{array}$ \\
\hline 1 PPI lead & $\begin{array}{l}1 \text { implementation } \\
\text { programme manager }\end{array}$ & $\begin{array}{l}3 \text { knowledge translation } \\
\text { project managers }\end{array}$ \\
\hline $\begin{array}{l}1 \text { communications } \\
\text { manager }\end{array}$ & & $\begin{array}{l}1 \text { knowledge translation } \\
\text { theme lead }\end{array}$ \\
\hline
\end{tabular}


Table 3: Updated taxonomy of boundary objects shared things or ideas around which communication and collaboration can be focused and coordinated

\begin{tabular}{|l|l|}
\hline Category & $\begin{array}{l}\text { Definition } \\
\text { Repositories }\end{array}$ \\
\hline $\begin{array}{l}\text { Standardised methods } \\
\text { \& forms }\end{array}$ & $\begin{array}{l}\text { Standardised format allows easy sharing and promotes } \\
\text { to different users at multiple sites } \\
\text { consistency of embedded and shared information } \\
\text { despite contextual and other differences between } \\
\text { settings and users }\end{array}$ \\
\hline Objects model \& maps & $\begin{array}{l}\text { Shared representations standing in for place, person, } \\
\text { process or idea, often simpler or abstracted in a way } \\
\text { that transmit a key point or interpretation free of the } \\
\text { complexity of the thing or idea as its exists naturally }\end{array}$ \\
\hline Symbolic objects & $\begin{array}{l}\text { Multiply interpreted conceptual and/or material things } \\
\text { or ideas which possess persuasive and emotive } \\
\text { properties }\end{array}$ \\
\hline
\end{tabular}

\section{Findings}

A range of boundary objects-in-theory (things, ideas or concepts that had potential to be boundary objects) and boundary objects in-use (things, ideas or concepts that operated as boundary objects) to facilitate (or sometimes hinder) boundary crossing necessary for knowledge mobilisation were identified across the three cases (Table 4). These objects variably conformed to the updated taxonomy. However as anticipated, classification in this way revealed little about whether these objects operated in practice. The context of the three cases differed not only in social and physical geography, but also in the way in which each CLAHRC interpreted and operationalised the expectation about applying research in practice. A service improvement approach was evident at Oakdown and Hazeldean, whilst Ashgrove focused on research and evaluation. However, there were common features in the ways in which boundary objects-in-theory 
and in-use were generated and engaged with, and in the factors which influenced their utility in practice. The following section is structured according to the themes 


\begin{tabular}{|c|c|c|c|c|}
\hline Case & Boundary Object & Origin & $\begin{array}{l}\text { Process of emergence/property } \\
\text { instilled }\end{array}$ & Effectiveness in use \\
\hline \multirow[t]{8}{*}{ Oakdown } & $\begin{array}{l}\text { Knowledge mobilsation } \\
\text { project proposal }\end{array}$ & $\begin{array}{l}\text { Developed by xxx using } \\
\text { the Knowledge to Action } \\
\text { cycle }\end{array}$ & $\begin{array}{l}\text { Co-production: Collaboration between } \\
\text { stakeholders }\end{array}$ & $\begin{array}{l}\text { Allowed negotiation of } \\
\text { organisational } \\
\text { boundaries }\end{array}$ \\
\hline & VTE assessment form & Department of Health tool & $\begin{array}{l}\text { Convergence: Adapted by boundary } \\
\text { spanners and frontline staff, appropriate } \\
\text { location identified to facilitate use. }\end{array}$ & $\begin{array}{l}\text { In use after appropriate } \\
\text { location identified. }\end{array}$ \\
\hline & MUST+ & $\begin{array}{l}\text { Validated tool to which } \\
\text { dieticians added questions }\end{array}$ & $\begin{array}{l}\text { Convergence: Adapted by frontline staff, } \\
\text { appropriate location identified to facilitate } \\
\text { use. }\end{array}$ & $\begin{array}{l}\text { In use after appropriate } \\
\text { location identified. }\end{array}$ \\
\hline & $\begin{array}{l}\text { "Evidence-based } \\
\text { practice" } \\
\text { and "service } \\
\text { improvement" }\end{array}$ & $\begin{array}{l}\text { Concepts in use among } \\
\text { healthcare practitioners }\end{array}$ & $\begin{array}{l}\text { Creation of meaningfulness for users: } \\
\text { Transition from theory to use required } \\
\text { recognition of language issues. }\end{array}$ & $\begin{array}{l}\text { Effective only when } \\
\text { terms meaningful to } \\
\text { stakeholders were used. }\end{array}$ \\
\hline & $\begin{array}{l}\text { "Patient Safety" and } \\
\text { "Everybody's business" }\end{array}$ & $\begin{array}{l}\text { Phrases spanning } \\
\text { stakeholder boundaries }\end{array}$ & $\begin{array}{l}\text { Frequent repetition led to reification but } \\
\text { remained } \\
\text { vague due to multiple meanings }\end{array}$ & $\begin{array}{l}\text { Highly resonant } \\
\text { symbolic boundary } \\
\text { object. }\end{array}$ \\
\hline & 'Nutrition' and 'dysphagia' & Widely shared clinical topics & $\begin{array}{l}\text { a priori concept harnessed and deployed by } \\
\text { boundary spanner to engage stakeholders } \\
\text { through shared meaning. }\end{array}$ & $\begin{array}{l}\text { A powerfully resonant } \\
\text { symbolic boundary } \\
\text { object, understood by all } \\
\text { stakeholders. }\end{array}$ \\
\hline & Nutrition action plan & Based on MUST+ & $\begin{array}{l}\text { Co-production by ward staff and CLAHRC } \\
\text { facilitators to make generic tool context } \\
\text { specific and meaningful. }\end{array}$ & $\begin{array}{l}\text { Highly effective, } \\
\text { regularly used by } \\
\text { frontline staff. }\end{array}$ \\
\hline & $\begin{array}{l}\text { Nutrition education } \\
\text { package }\end{array}$ & $\begin{array}{l}\text { Developed by CLAHRC } \\
\text { facilitators with NHS staff. }\end{array}$ & $\begin{array}{l}\text { Convergence: Co-production of tailored } \\
\text { package incorporating shared meaning. }\end{array}$ & Successful in use. \\
\hline \multirow[t]{3}{*}{ Hazeldean } & $\begin{array}{l}\text { Statistics such as national } \\
\text { data and local QOF data }\end{array}$ & Department of Health & $\begin{array}{l}\text { Top-down imposition -captured strategic } \\
\text { priorities but failed to reflect frontline } \\
\text { concerns }\end{array}$ & $\begin{array}{l}\text { Mixed levels of } \\
\text { meaningfulness } \\
\text { boundary object across } \\
\text { stakeholders although } \\
\text { has potential to improve } \\
\text { service delivery. }\end{array}$ \\
\hline & Disease registers & Local health authority & $\begin{array}{l}\text { Top-down imposition of disease registers for } \\
\text { GP practices. }\end{array}$ & $\begin{array}{l}\text { Ineffective: Inaccuracy } \\
\text { and lack of } \\
\text { standardisation } \\
\text { hampered improvement } \\
\text { work. }\end{array}$ \\
\hline & CLAHRC & $\begin{array}{l}\text { Department of Health, } \\
\text { NIHR }\end{array}$ & $\begin{array}{l}\text { Top-down imposition, the concept reflected } \\
\text { priorities at a senior organisational level. }\end{array}$ & $\begin{array}{l}\text { Concept generally } \\
\text { unhelpful to frontline } \\
\text { staff. }\end{array}$ \\
\hline
\end{tabular}




\begin{tabular}{|c|c|c|c|}
\hline $\begin{array}{l}\text { Heart Failure (HF) Alert } \\
\text { Card }\end{array}$ & Need identified by users & $\begin{array}{l}\text { Emergent: co-produced by stakeholders in } \\
\text { response to user need. }\end{array}$ & $\begin{array}{l}\text { Highly effective } \\
\text { boundary object. }\end{array}$ \\
\hline $\begin{array}{l}\text { Knowledge mobilisation } \\
\text { models and frameworks }\end{array}$ & Academia & Top-down, no local input. & $\begin{array}{l}\text { Possibly helpful for } \\
\text { coordination of projects } \\
\text { at an organisational } \\
\text { level, so may act as } \\
\text { boundary objects-in-use; } \\
\text { but can also inhibit } \\
\text { communication. }\end{array}$ \\
\hline $\begin{array}{l}\text { Physical health } \\
\text { assessment tool }\end{array}$ & $\begin{array}{l}\text { Linked with target set by } \\
\text { Trust }\end{array}$ & $\begin{array}{l}\text { Top-down imposition -captured strategic } \\
\text { priorities but failed to reflect frontline } \\
\text { concerns }\end{array}$ & $\begin{array}{l}\text { Met with resistance at } \\
\text { frontline. Not understood } \\
\text { or accepted by intended } \\
\text { users. }\end{array}$ \\
\hline $\begin{array}{l}\text { Chronic Kidney Disease } \\
\text { (CKD) Improvement } \\
\text { Guide }\end{array}$ & $\begin{array}{l}\text { Created by Hazeldean } \\
\text { boundary spanners using } \\
\text { resources } \\
\text { available }\end{array}$ & $\begin{array}{l}\text { Produced by boundary spanner but not co- } \\
\text { produced with patients or practitioners - } \\
\text { limiting convergence or meaningfulness }\end{array}$ & $\begin{array}{l}\text { Effective as part of a } \\
\text { complex intervention but } \\
\text { required a dedicated } \\
\text { facilitator. }\end{array}$ \\
\hline CKD audit tool & $\begin{array}{l}\text { Collaboration between } \\
\text { CLAHRCs } \\
\text { System developed by } \\
\text { CLAHRC team for use in } \\
\text { GP practices. }\end{array}$ & $\begin{array}{l}\text { Co-produced to a lesser degree as an } \\
\text { outcome of collaborative work }\end{array}$ & $\begin{array}{l}\text { Outcome of formal } \\
\text { collaboration but could } \\
\text { provoke rivalry. } \\
\text { Establishes baseline } \\
\text { data which could assist } \\
\text { knowledge mobilisation. } \\
\text { A boundary object-in- } \\
\text { theory, it provoked } \\
\text { territorialism and rivalry. } \\
\text { This reveals missed } \\
\text { treatment opportunities, } \\
\text { thus potentially } \\
\text { provoking resistance; it } \\
\text { can both hinder and } \\
\text { enable knowledge } \\
\text { mobilisation. }\end{array}$ \\
\hline Stroke Assessment Tool & $\begin{array}{l}\text { Developed by facilitator in } \\
\text { discussion with } \\
\text { stakeholders }\end{array}$ & $\begin{array}{l}\text { Co-produced with stakeholder with intention } \\
\text { to reflect stakeholder values and } \\
\text { perspectives (intended convergence) }\end{array}$ & $\begin{array}{l}\text { No information on } \\
\text { effectiveness - this is a } \\
\text { boundary object-in- } \\
\text { theory. }\end{array}$ \\
\hline $\begin{array}{l}\text { Change package/audit } \\
\text { tool/shared protocol }\end{array}$ & $\begin{array}{l}\text { Facilitators working with } \\
\text { practice teams }\end{array}$ & $\begin{array}{l}\text { Co-produced alongside practitioners to } \\
\text { develop a meaningful product }\end{array}$ & $\begin{array}{l}\text { Facilitates formation of } \\
\text { community of practice. }\end{array}$ \\
\hline
\end{tabular}




\begin{tabular}{|c|c|c|c|c|}
\hline \multirow[t]{5}{*}{ Ashgrove } & $\begin{array}{l}\text { Evaluation and } \\
\text { knowledge mobilisation } \\
\text { toolkits }\end{array}$ & $\begin{array}{l}\text { Developed by CLAHRC } \\
\text { team to enable users to } \\
\text { share information. }\end{array}$ & $\begin{array}{l}\text { Deliberate intent to increase uptake of } \\
\text { models and theories by re-packaging with } \\
\text { embedded user-relevant meaning }\end{array}$ & $\begin{array}{l}\text { Boundary objects-in- } \\
\text { theory which may } \\
\text { facilitate negotiation of } \\
\text { knowledge mobilisation } \\
\text { goals. }\end{array}$ \\
\hline & $\begin{array}{l}\text { Research opportunity } \\
\text { tool }\end{array}$ & $\begin{array}{l}\text { Developed by CLAHRC } \\
\text { team to bridge gap } \\
\text { between researchers and } \\
\text { service users }\end{array}$ & $\begin{array}{l}\text { Co-produced by researchers and } \\
\text { practitioners to identify shared concerns } \\
\text { thereby increasing convergence and } \\
\text { meaningfulness }\end{array}$ & $\begin{array}{l}\text { Unclear. Problems } \\
\text { around ownership and } \\
\text { sharing. }\end{array}$ \\
\hline & Diabetes risk score & $\begin{array}{l}\text { Initially developed by } \\
\text { CLAHRC team, later } \\
\text { revised with input from } \\
\text { stakeholders. }\end{array}$ & $\begin{array}{l}\text { Failure to engage in co-production resulted } \\
\text { in non-convergence of viewpoints and } \\
\text { production of tool unfit for practise }\end{array}$ & $\begin{array}{l}\text { Initially ineffective: } \\
\text { content inappropriate, } \\
\text { confusing and offensive } \\
\text { to target community. } \\
\text { After revision, this made } \\
\text { the transition to } \\
\text { boundary object-in-use. }\end{array}$ \\
\hline & $\begin{array}{l}\text { Cardiac e-rehab } \\
\text { programme }\end{array}$ & $\begin{array}{l}\text { Initially developed by } \\
\text { CLAHRC team, later } \\
\text { revised with input from } \\
\text { patients. }\end{array}$ & $\begin{array}{l}\text { Failure to co-produce initially led to poor } \\
\text { convergence and lack of meaningfulness. } \\
\text { Later iteration co-produced }\end{array}$ & $\begin{array}{l}\text { Initially ineffective, seen } \\
\text { as reflecting clinical } \\
\text { agenda rather than } \\
\text { patient experience. After } \\
\text { revision, this made the } \\
\text { transition to boundary } \\
\text { object-in-use. }\end{array}$ \\
\hline & CLAHRC & $\begin{array}{l}\text { Department of Health, } \\
\text { NIHR }\end{array}$ & $\begin{array}{l}\text { Knowledge mobilisation entity } \\
\text { commissioned by DH }\end{array}$ & $\begin{array}{l}\text { Required a process of } \\
\text { collective sense-making } \\
\text { to achieve clarity. }\end{array}$ \\
\hline
\end{tabular}

uncovered, starting from where boundary objects-in-theory and in-use were found to

emerge, what properties they possessed that made them appealing (or not), and the

process by which these were instilled as a consequence of their mode of emergence. 


\section{Emergence}

One of the most significant findings was the discovery of the way in which boundary objects-in-use emerged, developed and evolved through collective endeavour enacted between knowledge users and producers (Figure 1). This is apparent in all three cases, for example as demonstrated by the way in which a heart failure card at Hazeldean and malnutrition support tool at Oakdown, both emerged.

Emergence occurred in a number of ways. Some boundary objects were born through serendipity, unanticipated and organic. These objects emerged through interactions across boundaries, bubbling up at the site of collaboration to support and sustain communication between different stakeholders. Such objects were often shared things and ideas which possessed a natural affinity to transcend boundaries, or the flexibility which allowed them to be readily modified to fulfil a new purpose. An example was a heart failure alert card, co-developed to meet a user-identified need - facilitating communication between primary and secondary care services at Hazeldean:

that was something that came from ... the nurses really... The problem came from them and then we just tried to find a solution for it. (Susan, Hazeldean)

'This would be a good idea ...to adapt this and maybe use it for patients ... to improve communication' (Susan, Hazeldean). 
Figure 1. Interplay of properties

\section{AUTHENTIC}

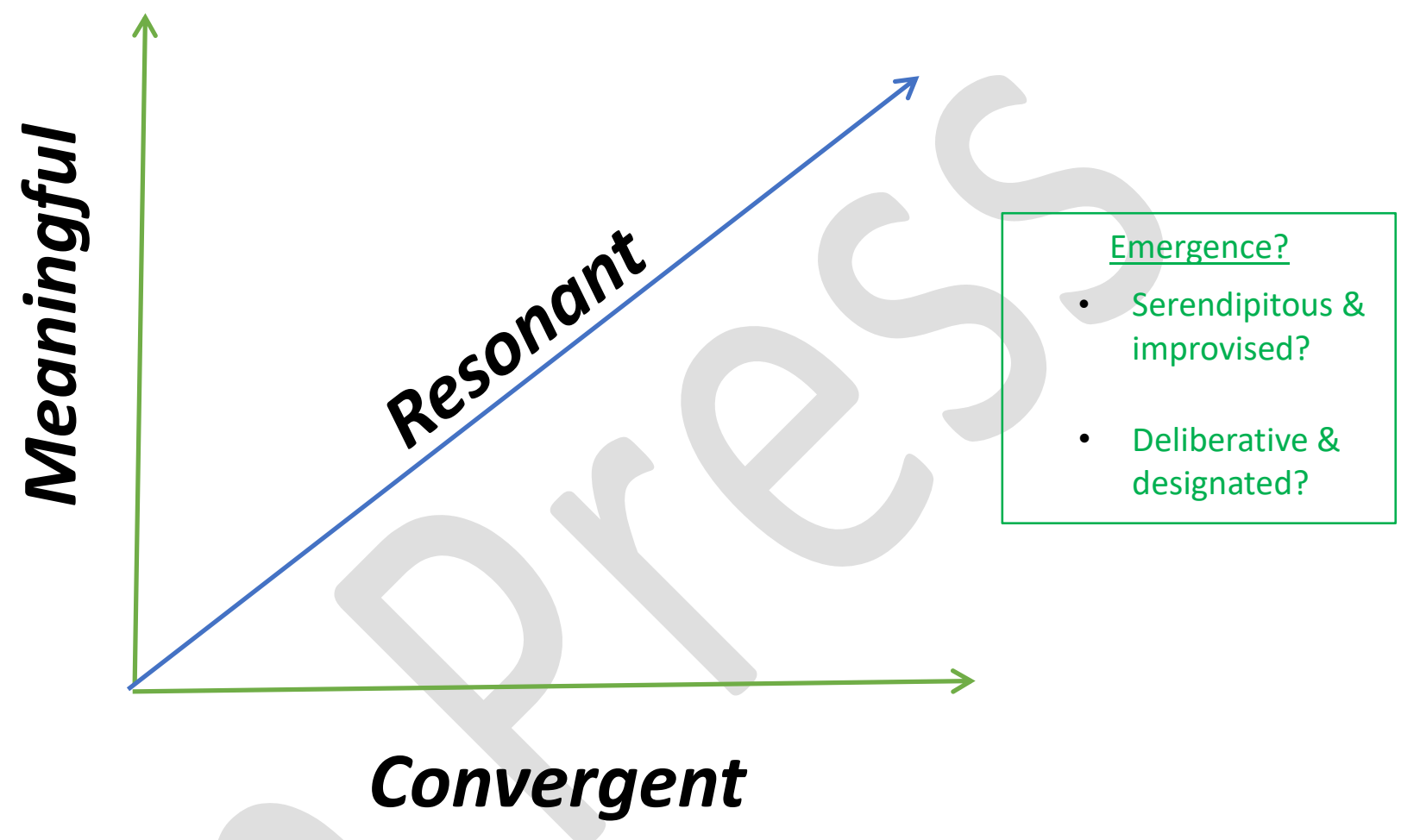

The heart failure alert card was also well received by patients, who reportedly "felt it legitimised the fact that they'd got heart failure because they had a card, a plastic card" (Susan, Hazeldean).

There were also boundary objects-in-theory which had been intended to bridge the gap between research and practice but which did not succeed in doing so. Many things and ideas described within documents relating to knowledge mobilisation published by each CLAHRC i.e. representing intended shared objects were identified as possessing some of the core properties of boundary objects on paper, but in practice they were found to be of limited utility, sometimes even contentious and divisionary (Table 2). 
An example of such an object was Ashgrove's diabetes assessment score. This had been adapted from a national evidence-based tool and was assumed that it would unify stakeholders as diabetes was a shared priority. However, in practice this tool was met with resistance, reinforcing some boundaries as it came to light that the tool had initially been developed without the input of its intended users. Despite representing a "seemingly very simple" online tool,

seven questions, very simple; age, your BMI, family history of high blood pressure, whether you're on any medication for high blood pressure, all these sorts of things...South Asian communities have a higher incidence of diabetes at a lower BMI ... and obviously Ashgrove has a very high South Asian population; it was really important that this tool worked for that group. (Judy, Ashgrove)

it was rejected by the intended users. The tool was withdrawn because as Judy stated, "they'd done a literal translation, which was in places quite offensive". Its use of common western concepts such as a 'traffic light system' to identify risk categories was problematic because the designers were unaware of the auspicious meanings of these colours. It was re-designed with the input of members of Ashgrove's South-Asian community, rectifying the translation to provide a more culturally attuned tool. Simply put by Judy at Ashgrove, "it would not have worked for that group if they hadn't had that conversation". The lesson learned was that objects designed in the absence of their intended users could reflect misplaced assumptions which could in turn alienate, rather than engage, stakeholders.

The influence of developer assumptions on whether a boundary object-in-theory became a boundary object-in-use was also found in other identified objects and ideas intended to span the research-practice gap. Examples included a physical health 
assessment tool for use with mental health service users which did not function as anticipated at Hazeldean. The concept and entity of CLAHRC itself was also found to reinforce the very boundaries the assessment tool was intended to bridge:

You know we've definitely crossed them but we've formed some as well and we think this is largely down to the way that the whole thing was set up. (Jaime, Hazeldean)

The sense that CLAHRC was somehow different was reiterated at Oakdown:

I got through to someone in an audit department and I tried to explain what it was about and he was obviously highly suspicious...as an outsider...and had obviously not heard of CLAHRC. (Jean, Oakdown)

A participant from Hazeldean reflected on why a physical health assessment tool had been difficult to implement. Resistance resulted from the perception that it represented a top-down agenda, rather than the needs and priorities of those care coordinators who were expected to use it:

I think the Trust themselves initially brought in the XXXX assessment because it was a target they had to do set by the commissioners. With no actual explanation of why it needed to be done, how it could be utilised (Dafydd, Hazeldean).

The utility of objects such as guidelines, protocols and clinical assessment tools was often limited by their formal content, rigid structure, and perceived links to a top-down agenda. The result was that such objects were felt to be imposed upon, rather than shared with, stakeholders. They characteristically possessed less flexible structures than those boundary objects which were improvised in situ, and required considerable tailoring to achieve the requisite level of interpretive flexibility. However, and with 
sufficient levels of stakeholder engagement, such tools could be adapted to meet local need, for example a malnutrition assessment tool (MUST plus) adapted to mobilise knowledge at Oakdown:

I mean to an extent MUST plus and the nursing care guidelines were very prescriptive ... we developed some action points...they chose three goals ... that they wanted to achieve within their area... I call it 'Pick and Mix', they ... picked and mixed what they wanted to do in their area ... and I think that was a good way really, rather than us telling them what to do. (Maureen, Oakdown)

Both Oakdown's malnutrition tool and Ashgrove's diabetes tool followed a path of development which was characterised by collective endeavour and episodes of trial and error during which each object was contextualised with knowledge contributed by stakeholders. If an object failed to follow this path of development, then it was likely to remain a boundary object-in-theory, rather than one in-use.

Whilst emergence could not always be predicted, it could be precipitated by people who were solution-focused, willing to improvise, and ready to recognise others' needs, as illustrated in the quote from Susan at Hazeldean above. The effectiveness of boundary spanners was linked to these skills and their ability to encourage stakeholders to participate in the process, thereby increasing the likelihood that a boundary object-inuse would emerge.

As data collection and analysis progressed, a theme identified as 'bricolage' surfaced. This provided a pragmatic explanation as to how, why, who and what was important in the generation of boundary objects which emerged through collective endeavour. 
The following section decribes a set of action-based properties which are proposed as a way of understanding the qualities of efcctive boundary objects in use in comparison to boundary objects-in-theory. In the spirit of Star's (1989) original conceptualisation these properties are sometimes overlapping and not always exclusive.

\section{Meaningfulness}

Meaningfulness primarily related to the values, associations, and discourses with which objects were ascribed according to user identity, interpretation and the context in which they were created and mobilised. If an object was insufficiently meaningful, then it was unlikely to appeal to prospective users. Both concepts and tools were found to struggle with the transition from boundary object-in-theory to boundary object-in-use across cases. For example, participants at Oaktown reported contrasting experiences using presumed shared concepts such as 'CLAHRC', and specific clinical conditions.

More impactful boundary objects were those which were found to be high in positive meanings and valued by multiple stakeholders across different contexts. A participant at Oakdown described the way in which the notion of 'nutrition' was a meaningful shared concept:

I think the thing with nutrition is it's not a hard sell... most people believe nutrition is important... So it's not a hard sell. What's the hard sell is how to do it. (Charlotte, Oakdown)

A counter example was the concept of 'CLAHRC' itself, which despite representing an intended shared concept was found to lack meaningfulness across all cases:

"I realised when I first started talking about CLAHRC... I had to really try and simplify it because all...the staff would just go 'What?', 'What?', CLAHRC, NIHR, 
all these they just didn't understand...you needed to make it more meaningful to them" (Bernie, Oakdown)

Suspiciousness of the entity was a common experience encountered by boundary spanners attempting to introduce the partnership across all three cases. At Oakdown a participant simply stated that "they don't know what it is", whilst others agreed that it was more a hindrance to opening up communication, actively obscuring the 'CLAHRC' brand in order to generate traction in the clinical area: "number one, you don't really mention CLAHRC, because nobody understands it” (Christy, Oakdown). Whilst meaningfulness was important in generating the appeal of an object, it did not guarantee it, nor did it imply that the embedded meanings were necessarily positive.

\section{Convergence}

Objects were more likely to succeed if they facilitated convergence of stakeholder perspectives. Convergence refers to the degree to which different priorities, agendas and viewpoints can be reconciled and aligned through the use of an object, generating a sense of ownership, and making visible common ground between stakeholders. This in turn provided a means to communicate and an incentive to cooperate. Convergence involved establishing a shared understanding between stakeholders reflecting overlapping concerns, as illustrated by the way in which a nutrition action plan was developed in partnership with the nursing team which was to use it at Oakdown. This captured formal guideline-based knowledge and combined it with local knowledge to generate an object which reflected a convergence of stakeholder views and was meaningful at different levels: 
The action plan was a way ... of giving them back some ... it was their action plan, they decided on it...So although it had some top down elements in that...they had to get better at using MUST plus, they decided ... how that would be done. And they decided what other objectives they would have around supporting people with oral nutrition. (Christy, Oakdown)

Recognising and appreciating this overlap could encourage cooperation across boundaries; for example, concepts that readily transcended boundaries were those that represented a convergence of patient and practitioner priorities. Like the concept of 'nutrition', dysphagia was found to have a unifying effect at Oakdown:

One of the things I always say about the dysphagia project is that I don't have any problem selling it as someone who's had anything to do with, worked with anyone who has swallowing problems, they're immediately on board. (Jean, Oakdown)

Dysphagia as a clinical concept and the experience of dealing with swallowing problems unified patients and practitioners so that they were able to work together across in order to develop a project which captured the concerns of all those involved, despite differing understandings.

\section{Resonance}

Resonance is defined by the Oxford English Dictionary (2002) as "Richness or significance, especially evoking an association or strong emotion" (p.711). Resonance played an important role in the way in which boundary objects were generated, responded to, and ultimately used (or not). Resonance was influenced by levels of meaningfulness and degree of convergence exhibited by an object. These qualities in 
turn influenced the object's potential to generate or inhibit alliance between stakeholders by resolving, or conversely, reinforcing boundaries. Resonance existed when the meanings embedded within an object were strong and convergence between stakeholders' perspectives and values was high. Rich examples of this were found across cases, for example the quotation from Jean, above.

Possessing high but negative meaningfulness alongside poor convergence led to a situation where a boundary object-in-theory lacked resonance amongst stakeholders. This was demonstrated by the response to assigning vascular conditions as an implementation priority without considering more local priorities at Hazeldean:

I think the problem was ...when this CLAHRC was set up ... we divided ourselves up into these four...therapy areas, Heart Disease, Stroke, Diabetes and Chronic Kidney disease, ... and it was just a case of sort of a finger in the air, right we'll give $X X X X$ Diabetes, and we'll give $X X X X \ldots$ you know, Chronic Kidney Disease and Diabetes, and without actually looking at ... what their ... priority areas of work were. (Tanya, Hazeldean)

This provides a contrast to the situation at Oakdown where knowledge mobilisation activities were driven by highly resonant and convergent clinical concerns.

\section{Authenticity}

Authenticity, here defined as a combination of the various action-based properties of objects which lent a shared symbolic dimension to boundary objects-in-use, was crucial to uptake. Authenticity arose when there was a high level of congruence between the combined meaningful, convergent and resonant properties of an object. Authenticity was generated and bestowed through collective processes to create an object which 
was credible, contextualised and collectively meaningful. The co-produced nutrition action plans at Oakdown illustrated this:

So the action plan I suppose was a ... was a boundary object... to cross that ... top down issue (Christy, Oakdown)

These objects were sufficiently embedded with the knowledge and values of each stakeholder group to provide a reference point around which collaborative endeavour could be formed over.

Findings suggested that an object could simultaneously possess both boundary spanning and boundary reinforcing properties; that is, under certain conditions a particular object may provide a fulcrum for either collaboration or conflict. This was the situation with a physical health assessment tool at Hazeldean:

It was set as a target, the team managers probably knew about it but in three out of four groups there was no understanding on the ground what it actually was, how to access it (Dafydd, Hazeldean)

Whilst structure of an object may be important, these findings show that the properties of boundary objects (the mode of emergence, alongside perceived levels of meaningfulness, convergence and resonance) played a larger role in how boundary objects operated in practice (Figure 1). A mismatch between these properties could lead to the generation of an object which was inhibitory rather than catalytic in terms of boundary spanning for knowledge mobilisation (see Box 1), lacking in perceived authenticity by its intended users 


\section{Discussion}

\section{Towards a new view of boundary objects}

This study proposes an updated taxonomy of boundary objects (Table 3), but moves beyond categorisation to explain what features characterise boundary objects which play effective roles in knowledge mobilisation, and how are they created. Attempts to classify potential boundary objects according to a structure-based taxonomy were shown to be inherently problematic when investigating their application to knowledge mobilisation, which is intrinsically complex, and requires flexibility and attention to context. Therefore, a new approach for understanding the types of things and ideas that were likely to operate as effective boundary objects-in-use was developed, moving away from taxonomy of type, towards a focus on the properties that enhanced their appeal and subsequent uptake in practice. This approach sits alongside Star's (1989) original definition, and builds upon her work by highlighting the characteristic combination of stability plus flexibility, the balance of which has often eluded those who have attempted to design and implement boundary objects (for example Henderson, 1991; Atwell, 2011; and Allen, 2014).

The emergence of boundary objects-in-use is important because it influences the overall uptake and appeal of shared objects in practice. Whether or not a boundary object makes the transition from in-theory to in-use is contingent on contextual factors including the identity of those involved in their creation, and whether such objects have emerged through a process of co-production, which can have either a catalytic or limiting influence on boundary spanning. Subsequently an object can possess both properties simultaneously, expressed at different levels or between different groups, referred to as 'scale' and 'scope' respectively by Star (2010). This supports a view of 
boundary objects proposed by Allan (2014), in which some objects can be identified as objects around which collaboration can be enacted (positive boundary objects), and simultaneously as objects which are contentious and volatile (negative boundary objects).

Boundary objects-in-theory and in-use can represent divergence (a lack of convergence between stakeholders' views and values) as a consequence of their association with an 'external' or imposed agenda. It was clear from the findings of this study that top-down imposition of boundary objects was likely to fail. For example, in Hazeldean, a tool designed to assess the physical health of mental health service-users was perceived as imposed (as a target) upon care co-ordinators and out of tune with frontline priorities. A similar struggle to introduce improvement packages in Hazeldean using targets and incentives to encourage best practice around a range of vascular diseases also ran into difficulties when it was found that the topics assigned to each primary care locality failed to match local clinical concerns. Establishing a sense of shared ownership could help improve uptake and appeal amongst intended users, as long as all relevant viewpoints were adequately represented and reconciled, as illustrated by the co-creation of a nutrition action plan with nursing staff at Oakdown. This co-productive process occurred at varying stages and to varying degrees during the lifecycle of boundary objects, when they were created, or at a later stage as they were reviewed, refined and amended in collaboration with stakeholders.

The importance of managing multiple perspectives in order to facilitate collaboration is highlighted by Du, Jing and Lui (2012), who demonstrated how a shared understanding between designers and consumers can lead to the production of products with the highest level of consumer satisfaction. Conversely, a lack of embedded shared vision 
results in an object that insufficiently reflects and reconciles all stakeholders' perspectives. Van Kammen (2003) discusses how failure to incorporate multiple user perspectives into an object can lead to the production of a "technological monster", a sophisticated object that is unattractive to users (p.20). This is comparable to the fate of the diabetes tool at Ashgrove, which initially failed to attract users due to erroneous embedded assumptions about what users wanted and needed.

Ramirez (1999) found that it was because of a sense of shared ownership that coproduced items were valued more highly, and for longer, a finding which is reflected in this study. For example, in Hazeldean the heart failure alert card demonstrated how shared ownership gave a sense of empowerment to the patients who used it during clinical encounters. In essence, a co-produced object is more likely to be an effective boundary object, reflecting and reconciling the needs and perspectives of users and producers.

Collective endeavour in which all relevant stakeholders are engaged is required to coproduce things and ideas that are meaningful to users, reflecting a preference for embedded 'local knowledge' which contextualised the objects to both use and user. This reinforces Clarke and Wilcockson's (2002) observation that there is a crucial distinction between 'knowledge for practice' and 'knowledge from practice'. Conflating these two types can lead to conflict and divergence, as for example with Ashgrove's diabetes risk tool (knowledge intended for practice), which represented designers' assumptions rather than users' understanding (knowledge from practice). The way in which this user-defined knowledge was embedded within an object, was a crucial factor in whether such an object would succeed in making the transition from intended boundary object-in-theory to actual boundary object-in-use. The requisite 
collective endeavour was found to be akin to bricolage, instigated by key boundary spanners acting as bricoleurs (Levi-Strauss, 1962). The manner in which boundary objects emerge and through this process are instilled with three properties (meaningfulness, convergence and resonance) which together contribute to the overall authenticity of an object is proposed as a way of unpacking what makes a boundary object, and why.

In this study, variable levels of stakeholder involvement in the initiation and development of boundary objects led to mixed levels of uptake. Increasing the way in which boundary objects are valued across all stakeholders and increasing their positive meaningfulness, resonance and authenticity by adopting a bricolage approach, can help to encourage uptake by instilling objects with relevant stakeholder knowledge and a sense of shared ownership. This increased commitment to using these objects because they possessed an intrinsically higher value to stakeholders, has important implications for policy and practice.

Make do and amend - bricolage and the creation of boundary objects.

Bricolage describes both a process and an outcome which has gained popularity across the organisational, business and entrepreneurship literatures (Levi-Straus, 1962;

Ferneley and Bell, 2006; Cuhna et al, 2010; Duymedjian and Ruling, 2010). It assumes that the hands-on knowledge possessed by the bricoleur extends to human, material and symbolic resources (Duymedjian and Ruling, 2010). The acceptance of a practice reality which is prone to unanticipated change, and is riven with the multiple perspectives of different stakeholders, lends bricolage a unique affinity for understanding the processes by which boundary objects emerge from theory to use in 
practice. Rather than creating a new tool for a novel purpose from newly acquired materials, bricoleurs are often constrained by limited resources and are adept at creating new tools from old materials. Baker and Nelson (2005) interpret the bricoleur's skill as the ability to create something from nothing, to use what others abandon, reject, leave behind or view as worthless. Fundamentally the bricoleur is 'hands on' experimenting, reframing, re-contextualising, imagining and manipulating (Cuhna et al, 2010).

Much of knowledge mobilisation in healthcare is focused on implementing standardised objects conveying codified knowledge, for example tools, guidelines, and pathways. A process of modification or tailoring is required during which objects are contextualised by supplementing with local user knowledge. This study reinforces the findings of earlier studies which highlight practitioner preference for tacit, local knowledge from practice rather than codified knowledge intended for practice. This is an often overlooked issue when attempts are made to mobilise knowledge through explicit and codified information like evidence-based guidelines (Clarke and Wilcockson, 2002). Recognising that such deeply contextualised local knowledge "fluctuates in time and between place and person" (p398) fits with this study's finding that the creation of a useful and effective boundary object is a collective process within which the intended users are active participants. The result is an object which is positively meaningful and highly resonant. Bricolage therefore provides a useful description of a process of creating, developing and amending boundary objects which is experimental, messy, frequently makeshift, often unpredictable, and involves collective endeavour between stakeholders instigated by bricoleurs as improvisers and an innovators of objects (Levi-Strauss, 1962). 
Boundary spanners possessing the skills of the bricoleur typically had an aptitude for taking that which is at hand - a guideline, protocol or tool - and through experimentation and improvisation, finding novel ways to translate and mobilise knowledge for practice creating boundary objects which were enriched by knowledge from practice. Thus the outputs of research would be melded with highly localised, contextualised knowledge which might lack initial visibility due to the assumptions, expectations, values and identities of those proposing implementation (Clarke and Wilcockson, 2002; Gabbay and Le May, 2004). Boundary objects created in partnership with stakeholders were often remodelled, amended with local knowledge, and contextualised in order to breathe life into otherwise static and formulaic objects. Thus a boundary object created through bricolage carries something of its creator with it (Levi-Strauss, 1962).

Bricolage has the potential to explain the way in which objects can become appealing and unappealing, contingent on the identity of both creator and intended user. By ensuring that the process of boundary object creation is one which is collective in nature, co-productive in principle, and conducted through a process of bricolage, it is possible to produce a final object imbued with the identities, perspectives, knowledge and values of all stakeholders, which may be more successfully mobilised across boundaries.

\section{Conclusion}

Boundary objects, by their nature, are imbued with social meaning. This study demonstrates how a process of collective endeavour (bricolage) must occur if objects are to become boundary objects-in-use. It offers a fresh perspective to explore an ongoing debate: when is something an effective boundary object, or not (Trompette and 
Vinck, 2009; Star, 2010), and what factors and processes influence this; as well as providing practical direction for the co-production of future boundary objects.

Understanding the way in which these properties and processes contribute to the overall authenticity of a boundary object has implications for the production of ideas, tools, things, services, and policies that are meaningful and appealing to users. Recognising that objects which superficially possess the structural qualities of boundary objects (boundary objects-in-theory) may not act as boundary objects-in-use has important implications in terms of future design and development of agile and appealing boundary objects-in-use, and for knowledge mobilisation as a whole. Boundary objects can exert either inhibitory or catalytic effects on the knowledge mobilisation process, depending on whether they are perceived in positive or negative ways. This builds on Star's (2010) argument that regardless of something's potential to be a boundary object, whether or not it becomes one is determined by the conditions and context of use and user.

The properties that make such objects useful and appealing are created through the process by which they emerge; these properties embody a convergence of stakeholders' views and values. These make the object meaningful and contribute to its level of symbolic resonance among stakeholders, so that it is perceived as authentic by users.

The greater it's perceived authenticity, the more likely it is that a boundary object-intheory will become a boundary object-in-use. Those objects which are perceived as inauthentic or which fail to take account of the needs and priorities of those who are expected to use them will not become effective boundary objects-in-use; indeed, they can have damaging, inhibitory effects, reinforcing boundaries rather than spanning them. 
We suggest that adopting a bricolage-driven approach to unify and align different stakeholders will increase the likelihood of generating effective boundary objects-in-use for improved knowledge mobilisation, be it healthcare or in other areas where the uptake of research knowledge and technological innovation is mandated. The level of engagement achieved between stakeholders will influence the overall impact and effectiveness of objects produced in this way.

\section{Acknowledgements:}

LMR acknowledges the tremendous debt of gratitude she owes Dr Arabella Melville for her infinite patience and unwavering support throughout the writing of this paper.

\section{References}

Ackerman, MS, Halverson, C, 2004, Organizational Memory as Objects, Processes, and Trajectories: An Examination of Organizational Memory in Use, Computer Supported Cooperative Work (CSCW), 13,155. Kluwer Academic Publishers

Allen, D, 2009, From boundary concept to boundary object: The practice and politics of care pathway development. Social Science \& Medicine, 69, 3 354-361

Allen, D, 2014, Lost in translation? 'Evidence' and the articulation of institutional logics in integrated care pathways: from positive to negative boundary object? Sociology of health and illness, 36, 6, 807-822. 
Atwell, G, 2011, The Challenge of Building Positive Boundary Objects

https://instructionaldesignfusions.wordpress.com/2011/04/23/the-challenge-of-buildingpositive-boundary-objects/

Baker, T, Nelson, RE, 2005, Creating something from nothing: Resource construction through entrepreneurial bricolage. Administrative science quarterly, 50, 3, 329-366.

Barrett, M, Oborn, E, 2010, Boundary object use in cross-cultural software development teams. Human Relations. 63,8, 1199-1221

Baumbusch, J, Reimer, Kirkham, S, Khan, K., Mcdonald, H.,Semeniuk, P, Tan, E. Anderson, J. (2008) Pursuing Common Agendas: A Collaborative Model for Knowledge Translation between Research and Practice in Clinical Settings. Research in Nursing \& Health, 31, 130-140

Blevins D, Farmer MS, Edlund C, Sullivan G, Kirchner JE, 2010, Collaborative Research between Clinicians and Researchers: a multiple case study of implementation. Implement Sci, 5, 76

Bowker, G, Star, SL, 1999, Sorting things out. Classification and its consequences. Cambridge: MIT Press

Briers, M, Chua, WF, 2001, The Role of actor-networks and boundary objects in management accounting change: a field study of an implementation of activity-based costing. Accounting, Organization and Society, 26, 237-269

Carlile, PR, 2002 A Pragmatic View of Knowledge and Boundaries: Boundary Objects in New Product Development. Organization Science, 13, 4, 442-455 
Clarke, C, Wilcockson, J, 2002, Seeing need and developing care: exploring knowledge for and from practice. International Journal of Nursing Studies. 39, 4, 397-406

Cooke J, Ariss, S, Smith C, Read, J, 2015 On-going collaborative priority-setting for research activity: a method of capacity building to reduce the research-practice translational gap. Health Res Policy Syst, 13, 25

Cunha, MP, Clegg, SR, Mendonça, S, 2010, On serendipity and organizing. European Management Journal, 28, 5, 319-330.

Damschroder, LJ, Aron, DC, Keith, RE, Kirsh, SR, Alexander, JA, Lowery, JC, 2009, Fostering implementation of health services research findings into practice: a consolidated framework for advancing implementation science. Implement Sci, 4, 1, 50

Du, J, Jing, S, Lui, J, 2012, Creating shared design thinking processes for collaborative design. Journal of Network and Computer Applications. 35, 11-120

Duymedjian, R, Rüling, C, 2010, Towards a foundation of bricolage in organization and management theory. Organization Studies, 31, 2, 133-151.

Estabrooks, CA, Thompson, DS, Lovely, J, JE, Hofmeyer, A, 2006, A guide to knowledge translation theory. Journal of Continuing Education in the Health Professions, 26, 1, 25-36.

Ferneley, E, Bell, F, 2006, Using bricolage to integrate business and information technology innovation in SMEs. Technovation, 26, 2, 232-241.

Fox, NJ, 2011, Boundary Objects, Social Meanings and the Success of New Technologies. Sociology, 45, 1, 70-85 
Fujimara, JH, 1992, Crafting Science: Standardized Packages, Boundary Objects and "Translation". Chapter 6 in Pickering, A. (Ed.) Science as Practice and Culture. Chicago: University of Chicago Press

Gabbay, J, Le May, A, 2004, Evidence based guidelines or collectively constructed "mindlines?" Ethnographic study of knowledge management in primary care BMJ 2004, 329,1013

Graham, ID, Logan, J, Harrison, MB, Straus, SE, Tetroe, J, Caswell, W, Robinson, N, 2006, Lost in knowledge translation: time for a map? Journal of continuing education in the health professions, 26, 1, 13-24.

Greenhalgh, T, Robert, G, Macfarlane, F, Bate, P, Kyriakidou, O, 2004, Diffusion of innovations in service organizations: systematic review and recommendations. Milbank Quarterly, 82, 4, 581-629.

Grimshaw, JM, Eccles, MP, Lavis, JN, Hill, SJ, Squires, JE, 2012, Knowledge translation of research findings, Implementation Science, 7, 1-17.

Henderson, K, 1991, Flexible Sketches and Inflexible Data Bases: Visual Communication, Conscription Devices, and Boundary Objects in Design Engineering. Science Technology Human Values, 16, 448-473

Kislov, R, Harvey, G, Walshe, K, 2011, Collaborations for Leadership in Applied Health Research and Care: lessons from the theory of communities of practice. Implement Sci, $6,64,5908-6$

Kitson, A, Harvey, G, McCormack, B, 1998, Enabling the implementation of evidence based practice: a conceptual framework. Quality in Health care, 7, 3, 149-158. 
Koskinen, KU, Mäkinen, S, 2009, Role of boundary objects in negotiations of projects contract. Int. J. Proj. Management, 27, 31-38

Levina, N, Vaast, E, 2005, The Emergence of Boundary Spanning Competence in Practice: Implications for Implementation and Use of Information Systems. MISQ. 29, 2

Levi-Strauss, C, 1962, The Savage Mind. London: Weidenfeld and Nicolson

Melville-Richards, L, 2015, Exploring and Explaining the Role of Boundary Objects in Implementation through the National Institute of Health Research's Collaborations for Leadership in Applied Health Research and Care (NIHR CLAHRCs). PhD thesis, Prifysgol Bangor University. http://e.bangor.ac.uk/10896/

National Institute for Health Research, 2008, Collaborations for Leadership in Applied Health Research and Care (CLAHRCs). www.nihr.ac.uk/infrastructure

\section{/Pages/CLAHRCs.aspx}

Nicolini, D, Powell, J, Conville, P, Martinez-Solano, L, 2008, Managing knowledge in the healthcare sector. A review. Int. J. Of Management Reviews, 10, 3, 245-263

Nonaka, I, 1994, A dynamic theory of knowledge creation, Organization Science, $5,1,14-37$.

Nowotny, H, Scott, P, Gibbons, M, 2001, Re-Thinking Science: Knowledge and the Public in an Age of Uncertainty, Blackwell, Oxford.

Nutley, SM, Davies, HT, 2001, Developing organizational learning in the NHS. Medical education, 35, 1, 35-42. 
Oborn, E, Barrett, M, Racko, G, 2010, Knowledge translation in healthcare: A review of the literature. Working Paper Series 5/2010, JBS Cambridge

Osterlund, C, Crowston, K, 2013, Boundary-Spanning Documents in Online FLOSS Communities: Does One Size Fit All?, 46th Hawaii International Conference on System Sciences (HICSS), Wailea, Maui, HI USA, 2013, 1600-1609.

Patton, MQ, 2002, Qualitative research and evaluation methods. Thousand Oaks: Sage.

Phelps, AF, Reddy, M, 2009, The Influence of Boundary Objects on Group Collaboration in Construction Project Teams. GROUP '09, 125-128

Ramirez, R, 1999, Value co-production: intellectual origins and implications for practice and research. Strategic Management Journal, 20, 1, 49-65

Reddy, M, Dourish, P, Pratt, W, 2001, Coordinating Heterogeneous Work: Information and Representation in Medical Care. Proceedings of European Conference on CSCW $01,239-258$

Ritchie, J, Lewis, J, 2003, A Guide for Social Science Students and Researchers. London: Sage

Ritchie J, Spencer, L, 1994, Qualitative data analysis for applied policy research. In Analysing Qualitative Data (Bryman A., Burgess R.G., Eds), Routledge, London, 172194

Rycroft-Malone, J, Burton, C, Wilkinson, J, Harvey, G, McCormack, B, Baker, R, Dopson, S, Graham, I, Staniszewska, S, Thompson, C, Ariss,S, Melville-Richards, L, Williams, L, 2015, Collective action for knowledge mobilisation: a realist evaluation of 
the Collaborations for Leadership in Applied Health Research and Care. Health Serv Deliv Res. 3.44

Rycroft-Malone, J, Burton, CR, Wilkinson, J, Harvey, G, McCormack, B, Baker, R, Dopson, S, Graham, ID, Staniszewska, S, Thompson, C, Ariss, S, Melville-Richards, L, Williams, L, 2016, Collective action for implementation: a realist evaluation of organisational collaboration in healthcare Implementation Sci. 11,17

Rycroft-Malone, J, Harvey, G, Seers, K, Kitson, A, McCormack, B, Titchen, A, 2004, An exploration of the factors that influence the implementation of evidence into practice. Journal of clinical nursing, 13, 8, 913-924.

Simons, H, 2009, Case Study Research in Practice. London: Sage

Star, SL, Griesemer, JR, 1989, Institutional Ecology, "Translations", and Boundary Objects: Amateurs and Professionals in Berkeley's Museum of Vertebrate Zoology, 1907-39 Chapter 33 in Biagioli, M, 1999 (Ed.) The Science Studies Reader. London: Routledge.

Star, SL, 2010, This is not a boundary object: Reflections on the origin of a concept. Science, Technology and Human Values, 35, 5, 601-617.

Stenfors, S, Tanner, L, Haapalinna, I, 2004, Executive Use of Strategy Tools: Building Shared Understandings through Boundary Objects. Frontiers of E-Business Research $2004,635-645$

Thomas, G, 2011, How to do your Case Study - A Guide for Students and Researchers. London: Sage 
Trompette, P, Vinck, D, 2009, Revisiting the notion of Boundary Object, Revue d'anthropologie des connaissances 3, 1, 3-25.

Van Kammen, J, 2003, Who represents the users? Critical encounters between women's health advocates and scientists in contraceptive research and development.' Chapter 7 in Oudshoorn, N, Pinch, T (2003) (Eds) How Users Matter: The coconstruction of users and technologies, 151-171. Cambridge: MIT Press

Williams, P, 2012, Collaboration in Public Policy and Practice: Perspectives on boundary spanners. Bristol: The Policy Press

Winget, M A, 2007, A methodology and model for studying boundary objects, annotations, and collaborative practices: Musicians and musical scores. Proceedings of the American Society for Information Science and Technology. 44, 1, 1-13 